
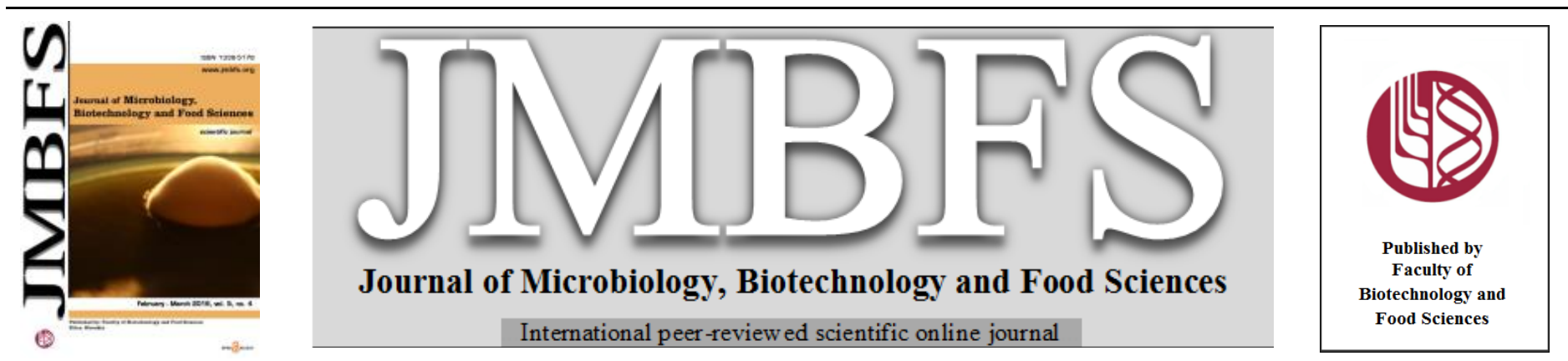

\title{
AN EFFICIENT RECOVERY OF TRANSGENIC PLANTS FROM A TROPICAL INDIAN MAIZE INBRED LINE
}

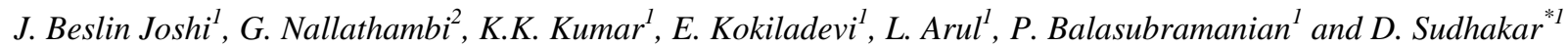

Address(es): D. Sudhakar,

${ }^{1}$ Department of Plant Biotechnology, Centre for Plant Molecular Biology and Biotechnology, Tamil Nadu Agricultural University, Coimbatore.

${ }^{2}$ Department of Millets, Centre for Plant Breeding and Genetics, Tamil Nadu Agricultural University, Coimbatore.

*Corresponding author: dsudhakar@hotmail.com

doi: 10.15414/jmbfs.2016.5.4.335-340

\section{ARTICLE INFO}

Received 12. 6. 2014

Revised 2. 11. 2015

Accepted 5. 11. 2015

Published 1. 2. 2016

Regular article

open $\odot$ access

\begin{abstract}
Tropical Indian maize inbreds are known for their recalcitrance in tissue culture which is a prerequisite for development of transgenic lines from such cultivars. In the present study, particle bombardment-mediated transformation of a tropical Indian maize inbred line, UMI29 was attempted. Parameters that infulence transforamation efficiency such as size of embryo (1.5 mm and $2.0 \mathrm{~mm})$, micro-carrier flying distance $(6 \mathrm{~cm}$ and $9 \mathrm{~cm})$ and post-bombardment resting period $(2,7$ and 10 days $)$ on transient and stable expression of transgene were investigated. The greatest transformation efficiency of $2.67 \%$ was obtained using immature embryos of $1.5 \mathrm{~mm}$ at $6 \mathrm{~cm}$ of microcarrier flying distance with a resting period of 2 days. Stable inheritance of transgenes, viz., gusA and bar was confirmed in $\mathrm{T}_{1}$ lines.
\end{abstract}

Keywords: Maize, particle bombardment, gusA, bar, transgenic plants

\section{INTRODUCTION}

Maize is one of the most important food staples in the world. In 2011-2012, the worldwide maize production was about 877 million tonnes and accounted for about $24 \%$ of the total cereal production (www.igc.int; retrieved on 10.4.2014) Though conventional breeding tools are most widely used in crop improvement, biotechnological tools widened the scope of crop improvement by way of helping scientists to understand the roles of different genes and engender foreign genes in the plant with a view to imparting novel and beneficial traits. Several genetic engineering studies have been focused on maize since 1990 after achieving regeneration of complete fertile plant through Biolistic ${ }^{\circledR}$ method (GordonKamm et al., 1990). Later, Agrobacterium-mediated maize transformation was also demonstrated using super binary vector (Agrobacterium strains harbouring extra copies of $\operatorname{vir} B, \operatorname{vir} C$ and $\operatorname{vir} G$ ) (Ishida et al., 1996; Negrotto et al., 2000; Frame et al., 2002 and Miller et al., 2002). Success of either method of gene delivery chiefly depends on genotypes which are capable of producing highly competent embryogenic calli with regeneration potential. Somatic embryogenesis in maize is controlled by one or a group of several genes and the QTL associated were identified (Krakowsky $\boldsymbol{e t}$ al., 2006). Many temperate maize genotypes are able to regenerate plants from tissue culture (Vasil et al., 1985; Duncan et al., 1985; Tomes and Smith, 1985; Hodges et al., 1986), while on the other hand, a fewer genotypes adapted to tropical areas have exhibited the capacity to produce Type II callus and plant regeneration from tissue culture (Bohorova et al., 1995; Danson et al., 2006). Maize transformation was successfully achieved using the temperate maize such as hybrid HiII (A188 X B73), harbouring genes for somatic embryogenesis from the A188 genotype (González et al., 2012). However, such transformation system is not available for tropical maize and they are considered recalcitrant for genetic transformation. In this study, with a view to developing a high frequency transformation protocol, we optimised different parameters which influence generation of transgenic plants in maize. We studied the effect of size of the immature embryos, microcarrier flying distance and resting period on transient and stable expression of transgene.

\section{MATERIAL AND METHODS}

\section{Plant material and immature embryo culture}

A relatively more tissue culture-responsive Indian tropical maize inbred line, UMI29 was used in this study. Cobs were harvested 8-12 DAP and used for isolation of immature embryos. The husk was removed and the cobs surface sterilised using $2.5 \%$ sodium hypochlorite for $5 \mathrm{~min}$ followed by three washes with sterile distilled water. Immature embryos of 1.5 and $2.0 \mathrm{~mm}$-long were excised aseptically from sterilized immature cobs using a sterile scalpel as described by Frame $\boldsymbol{e t}$ al. (2002). Isolated immature embryos were cultured in vitro with their scutella facing upward on the callus induction medium (N6 medium supplemented with $1 \mathrm{mg} / 1$ 2,4-D, $15 \mu \mathrm{M}$ DICAMBA, $10 \mathrm{mg} / 1 \mathrm{AgNO}_{3}$ and $2.88 \mathrm{~g} / \mathrm{l}$ proline) placed for 4 days in the dark at $25 \pm 2{ }^{\circ} \mathrm{C}$ prior to bombardment.

Plasmid

The immature embryos were bombarded with pAHC25 (Christensen \& Quail, 1996) which contains bar gene, the selectable marker gene conferring resistance to the herbicide, phosphionthricin and $\beta$-glucuronidase (gus) gene, the reporter gene, either of them placed under the control of a maize ubiquitin 1 (ubi-1) promoter (Figure 1).

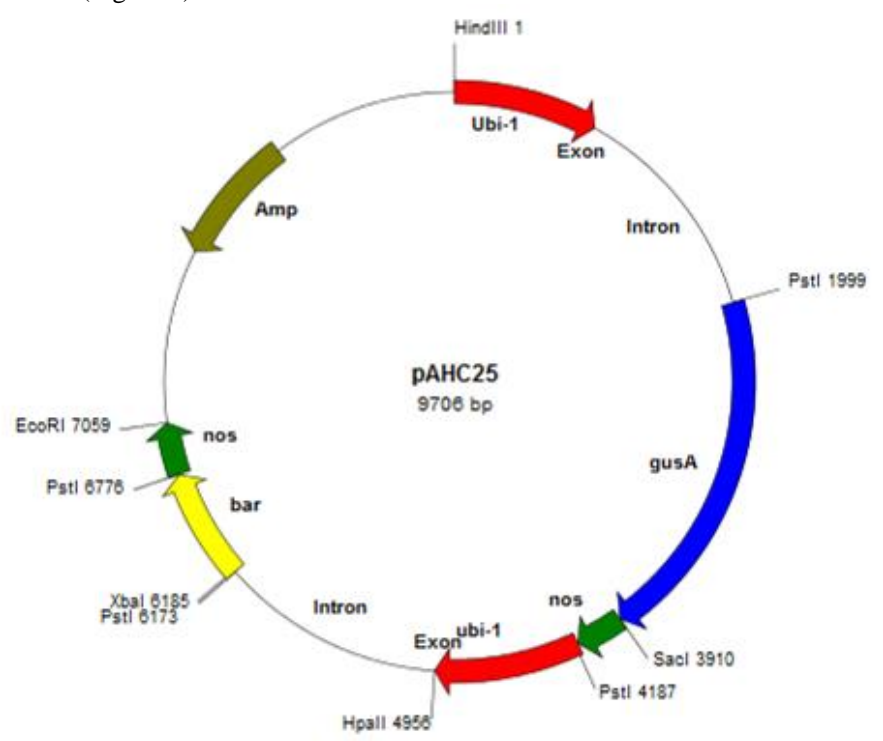

Figure 1 Physical map of pAHC25 vector 


\section{Particle bombardment}

The pre-cultured immature embryos (1.5 or $2.0 \mathrm{~mm}$ long) were arranged at the centre of the plate containing osmoticum medium (callus induction medium containing $36.4 \mathrm{~g} / \mathrm{l}$ mannitol and $36.4 \mathrm{~g} / \mathrm{l}$ sorbitol) with scutella facing upward 4 hours prior to bombardment. The embryos were bombarded twice at a 6 or $9 \mathrm{~cm}$ microcarrier flying distance with the DNA coated onto $0.9 \mu \mathrm{m}$ dia gold particles (prepared as described by the manufacturer) using the PDS 1000/He device (Biorad, USA) with a 4 hour interval in between. The bombarded embryos were transferred onto a fresh callus induction medium 16 hour post bombardment treatment on osmoticum medium.

\section{Selection}

On the lapse of 2, 7 or 10 days of resting period meant for facilitating an easy recovery from the bombardment shock, the embryos were transferred onto a selection medium (callus induction medium containing $3 \mathrm{mg} / \mathrm{l}$ phosphinothricin) and incubated in the dark at $25 \pm 2{ }^{\circ} \mathrm{C}$. The cultures were sub-cultured onto a fresh selection medium at a 15 -day interval and maintained in the dark at $25 \pm 2{ }^{\circ} \mathrm{C}$.

\section{Shoot initiation and regeneration}

The embryogenic calli that withstood three rounds of phosphinothricin selection were transferred onto a regeneration medium (MS medium supplemented with 1 $\mathrm{mg} / \mathrm{l} \mathrm{kinetin}$ and $1 \mathrm{mg} / \mathrm{l} \mathrm{BAP}$ ) and incubated under 16 hours of light and 8 hours of dark at $25 \pm 2{ }^{\circ} \mathrm{C}$ in a plant growth chamber. The matured somatic embryos germinated on the regeneration medium produced roots and shoots.

\section{Shoot elongation and root proliferation}

The shoots of $3-5 \mathrm{~cm}$ in length with primary roots were transferred to MS medium and incubated at $25 \pm 2{ }^{\circ} \mathrm{C}$ with a photoperiod of 16 hours light and 8 hours dark in a plant growth chamber for elongation of shoots and induction of secondary roots. The plantlets with 2-3 well developed leaves were forwarded for hardening.

\section{Hardening}

The plants with well developed root and shoot system were transferred to sterile pots containing sterile soil, sand and vermicompost mixture in 1:1:1 ratio maintained in a culture room at $25 \pm 2{ }^{\circ} \mathrm{C}$ under 16 hours of light for $10-15$ days After the plant had produced 1-2 healthy leaves, they were transferred to transgenic greenhouse.

\section{PCR analysis}

The presence of gusA gene in the transformed plants was confirmed by a PCR amplification of $878 \mathrm{bp}$ of an internal fragment of gusA gene using a set of primers, GUS1F (5'CAACGAACTGAACTGGCAGA3') and GUS1R (5’TTTTTGTCACGCGCTATCAG3').

\section{GUS assay}

GUS analysis was carried out as described by Jefferson (1987). Transient GUS expression assay was carried out 48 hours after second bombardment in the bombarded and control embryos and the number of blue spots per embryo was scored. In the stable GUS assay, GUS expression was studied in different plant parts (leaf bit, seed and bract) of the putative transgenic $\left(\mathrm{T}_{0}\right)$ and control plants.

\section{Basta leaf painting assay}

The Basta leaf painting assay was carried out on a photosynthetically active third leaf. At the centre of the third leaf, $5 \mathrm{~cm}$ area was marked and was swabbed with cotton soaked in $1.0 \%$ Basta solution containing $0.1 \%$ tween 20 . Seven days after Basta painting, the leaves were scored for herbicide tolerance. A control was maintained by using the same procedure in the wild type UMI29 plants.

\section{Statistical analysis}

The data were analysed using AgRes Statistical Software, Version 3.01 (Pascal International Software Solutions, 1994). ANOVA was worked out on the data transformed by arcsine or square root transformation of the percentage or count data, followed by least significant difference (LSD) test to select the best treatment. Mean and standard error were performed in worksheet format using the data analysis tool pack feature available in MS Office Excel 2007 software.

\section{RESULTS AND DISCUSSION}

Several factors are known to influence genetic transformation efficiency of particle bombardment-mediated method and optimization of these parameters is critical to recover transgenic plants with high transformation efficiency. Immature embryos of UMI29, an Indian tropical maize inbred were used as explants in particle bombardment experiments. The immature embryos are sporophytic tissue capable of producing somatic embryos which eventually give rise to plants. Due to their amenability for tissue culture and regeneration, immature embryos are the most widely used explants in maize in vitro culture (Green and Phillips, 1975; Armstrong and Green, 1985; Rafiq et al., 2005; Jakubeková et al., 2011; Manivannan et al., 2010, González et al., 2012).

\section{Size of the immature embryo}

The size of the immature embryo used is one of the biological factors that affect the culture response and transformation efficiency. When two different sizes of embryos (1.5 and $2.0 \mathrm{~mm}$ ) were bombarded, these bombarded immature embryos produced four different types of calli namely, Type I, Type II, non embryogenic and rhizogenic calli on selection medium. Among them, Type I and Type II calli which were capable of regeneration were forwarded to further rounds of selection. On the other hand, the embryos that could not withstand selection either remained as such and died or formed watery calli that later turned brown and died. The embryogenic calli originated six days after culture in $1.5 \mathrm{~mm}$ embryos and 10 days after in $2.0 \mathrm{~mm}$ sized embryos. The embryo of $1.5 \mathrm{~mm}$ long produced callus predominantly of Type II nature (74\%) while $2.0 \mathrm{~mm}$ embryos produced callus mostly of Type I nature (31\%; Tab 1). The use of Type I and Type II calli in producing regenerable plants after bombardment were reported by earlier workers (Brettschneider et al., 1997; Frame $\boldsymbol{e t}$ al., 2000). The $1.5 \mathrm{~mm}$ long embryos were tender and young enough to undergo complete dedifferentiation while $2.0 \mathrm{~mm}$ long embryos produced large nodular embryogenic calli from the scutellar region (Figure 2). Since the 1-2 layer thick mantle of embryogenic units were capable of regeneration, genetic transformation targeting this region in both the sizes of embryos produced stable GUS expressing transformed plants $(1.5 \mathrm{~mm}$ embryos produced 7 plants and 2.0 mm embryos produced 3 plants; Tab 1 ). Similar reports on recovery of transgenic maize plants by targeting the surface cell layers of scutellum were reported by Vasil et al. (1985), Kausch et al. (1995) and Kemper et al. (1996).

Table 1 Effect of embryo size on type I and type II callus induction frequency and particle bombardment-mediated transformation of maize.

\begin{tabular}{lccc} 
Embryo size & Type I (\%) & Type II (\%) & $\begin{array}{c}\text { Number of PCR } \\
\text { positive and GUS } \\
\text { expressing plants } \\
\text { obtained }\end{array}$ \\
\hline $1.5 \mathrm{~mm}$ & $18.00 \pm 3.39^{\mathrm{b}}$ & $74.00 \pm 6.18^{\mathrm{a}}$ & $1.4 \pm 0.50^{\mathrm{a}}(7)$ \\
$2.0 \mathrm{~mm}$ & $31.00 \pm 3.14^{\mathrm{a}}$ & $53.00 \pm 7.89^{\mathrm{b}}$ & $0.6 \pm 0.40^{\mathrm{b}}(3)$
\end{tabular}

Legend: Each treatment was replicated 5 times with 60 explants per replication. The values presented are as mean \pm SE followed by alphabets to imply significant difference $(\mathrm{p} \leq 0.05)$ after grouping of treatment means after ANOVA by LSD and values with same letter are not significantly different. Percentage data has been transformed by the arc-sine transformation and count data by square root transformation prior to analysis. Value within the parenthesis is the total number of plants obtained in each treatment.

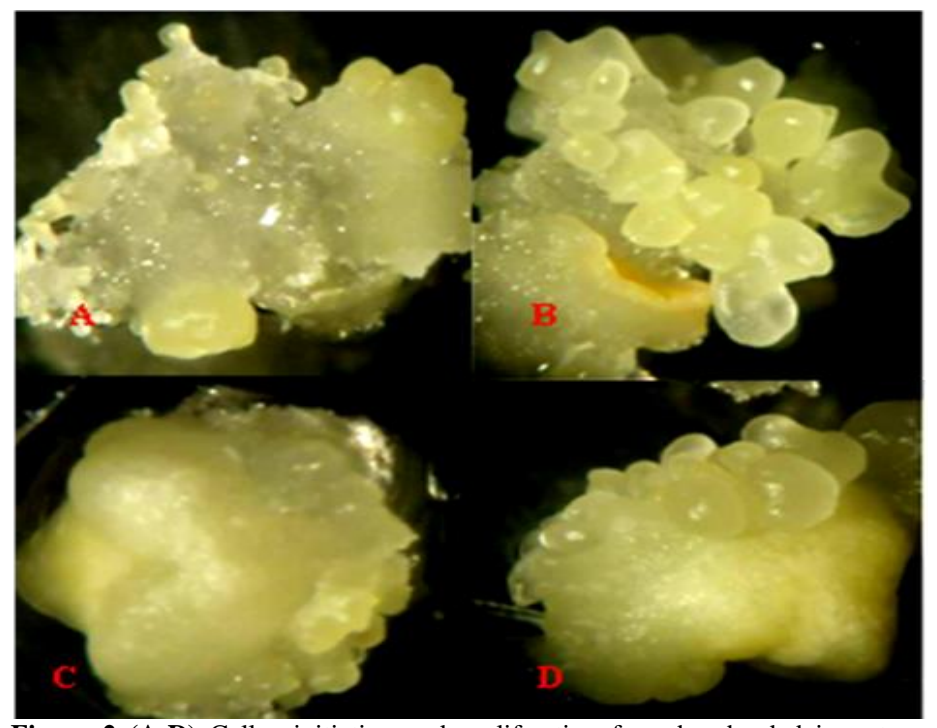

Figure 2 (A-D) Callus initiation and proliferation from bombarded immature maize embryos of UMI29: $1.5 \mathrm{~mm}$ long embryos (A,B); $2.0 \mathrm{~mm}$ long embryos (C,D) 


\section{Resting period}

Different periods of resting (2, 7 and 10 days) were given to immature embryos post-bombardment in order for allowing the proliferation of transformed calli before subjecting them to selection pressure. With an increase in resting period, the number of calli that survived in selection got increased (Tab 2). However, a two-day resting period generated the greatest number of GUS expressing transgenic plants (4 plants), while that associated with 7 and 10 day resting periods produced 3 plants each (Tab 2). Resting period of two days was found to be sufficient for recovering the greatest number of transformants. Besides it was found that the number of escapes was the least in two-day resting. A two-day resting period was adopted by Vain et al. (1993) while 10 and 14 days of resting were adopted in maize biolistic transformation by El-Itriby et al. (2003); Oneto et al. (2010); Frame et al. (2000) and Petrillo et al. (2008).

Table 2 Effect of resting period on particle bombardment-mediated maize transformation

\begin{tabular}{lccc}
$\begin{array}{l}\text { Resting } \\
\text { period }\end{array}$ & $\begin{array}{c}\text { No. of calli } \\
\text { selected }\end{array}$ & $\begin{array}{c}\text { No. of plants } \\
\text { regenerated }\end{array}$ & $\begin{array}{c}\text { No. of PCR positive } \\
\text { and GUS } \\
\text { expressing plants }\end{array}$ \\
\hline $2 \mathrm{~d}$ & $14.00 \pm 0.48^{\mathrm{c}}(70)$ & $7.00 \pm 0.54^{\mathrm{b}}(35)$ & $0.80 \pm 0.37^{\mathrm{NS}}(4)$ \\
$7 \mathrm{~d}$ & $19.20 \pm 0.43^{\mathrm{b}}(96)$ & $8.00 \pm 0.47^{\mathrm{b}}(40)$ & $0.60 \pm 0.24^{\mathrm{NS}}(3)$ \\
$10 \mathrm{~d}$ & $25.60 \pm 0.48^{\mathrm{a}}(128)$ & $10.20 \pm 0.48^{\mathrm{a}}(51)$ & $0.60 \pm 0.24^{\mathrm{NS}}(3)$ \\
\hline
\end{tabular}

Legend: Each treatment was replicated 5 times with 40 explants per replication. The values presented are as mean \pm SE followed by alphabets to imply significant difference $(\mathrm{p} \leq 0.05)$ after grouping of treatment means after ANOVA by LSD and values with same letter are not significantly different. Count data has been transformed by the by square root transformation prior to analysis. NS - not significant. Value within the parenthesis is the total number of plants obtained in each treatment.

\section{Microcarrier flying distance}

The microcarrrier flying distance (the distance from the microprojectile launch site to the biological target) is one of the critical physical factors that affect the transformation efficiency. Sanford et al. (1993) observed that the microcarrier flying distance was critical when working with small microcarriers and had to be minimised to maintain adequate velocity. With the increase in distance of flying distace the velocity of microprojectiles gets reduced, resulting in less penetration of microprojectiles into the callus. A higher number of transient GUS expression spots were detected when explants were placed at $6 \mathrm{~cm}$ (71.6 spots) microcarrier flying distance compared to $9 \mathrm{~cm}$ (53.4) distance (Tab 3; Figure 3). The number of stable transformants generated was also maximum at $6 \mathrm{~cm}$ microcarrier flying distance (Tab 3). Tadesse et al. (2003) and Petrillo et al. (2008) reported similar results of higher number of transient GUS expression as well as stable transformation events at a microcarrier flying distance of $6 \mathrm{~cm}$ compared to 12 or $13 \mathrm{~cm}$.

Table 3 Effect of microcarrier flying distance on transient and stable GUS expression and transformation efficiency.

\begin{tabular}{lccc}
\hline $\begin{array}{l}\text { Micro carrier } \\
\text { flying distance }\end{array}$ & $\begin{array}{c}\text { Transient GUS } \\
\text { spots (Mean } \pm \\
\text { SE) }\end{array}$ & $\begin{array}{c}\text { Stable GUS } \\
\text { expressing } \\
\text { plants }\end{array}$ & $\begin{array}{c}\text { Transformation } \\
\text { efficiency (\%) }\end{array}$ \\
\hline $6 \mathrm{~cm}$ & $71.60 \pm 12.49^{\mathrm{a}}$ & $1.4 \pm 0.50^{\mathrm{a}}(7)$ & 2.33 \\
$9 \mathrm{~cm}$ & $53.40 \pm 7.90^{\mathrm{b}}$ & $0.6 \pm 0.40^{\mathrm{b}}(3)$ & 1.00 \\
\hline
\end{tabular}

Legend: Each treatment was replicated 5 times with 60 explants per replication. The values presented are as mean \pm SE followed by alphabets to imply significant difference $(\mathrm{p} \leq 0.05)$ after grouping of treatment means after ANOVA by LSD and values with same letter are not significantly different. Count data has been transformed by square root transformation prior to analysis.

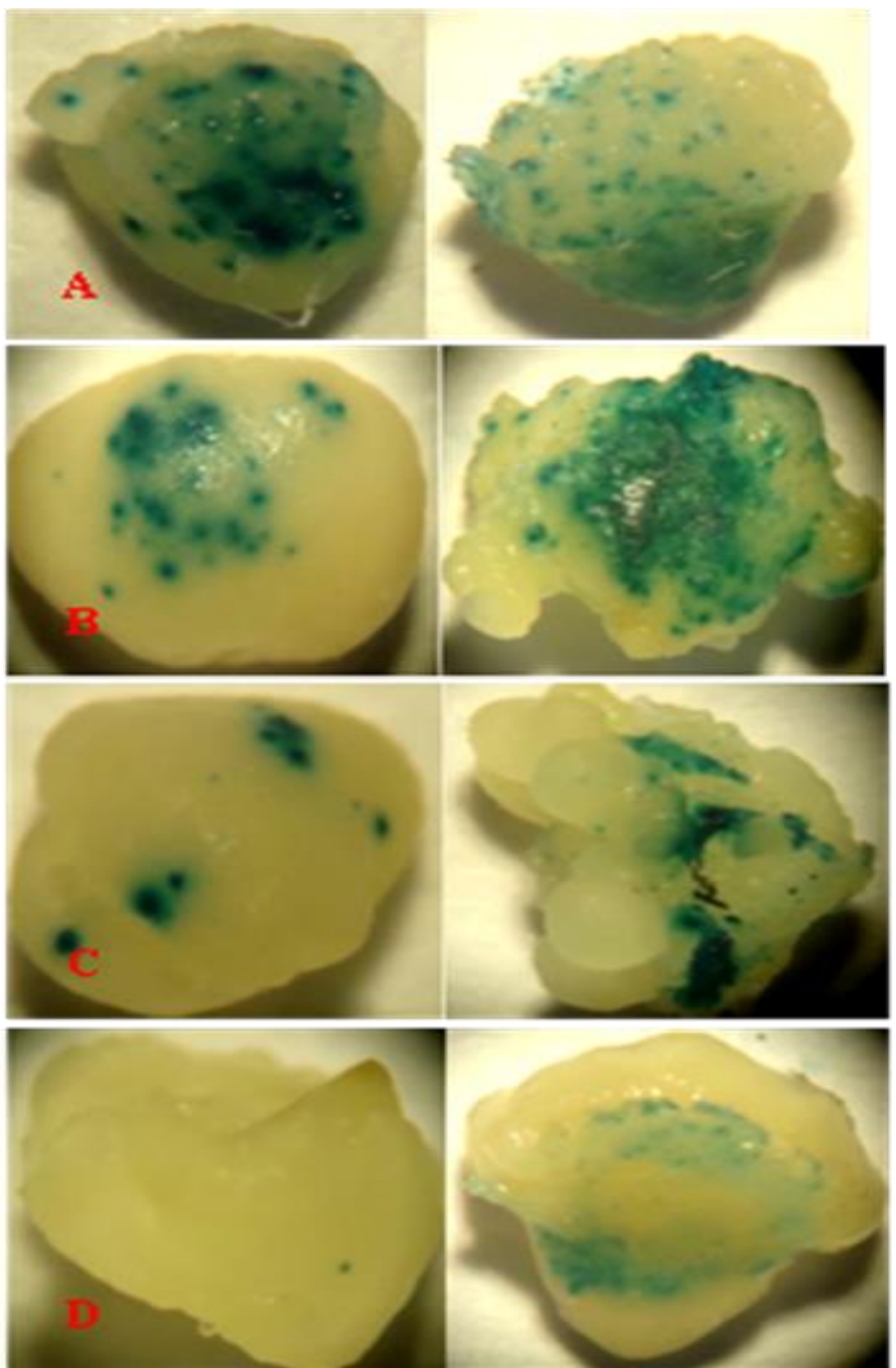

Figure 3 (A-D) Transient GUS expression in bombarded immature maize embryos at different microcarrier flying distance: $1.5 \mathrm{~mm}$ size at $6 \mathrm{~cm}$ distance (A); $2.0 \mathrm{~mm}$ size at $6 \mathrm{~cm}$ distance (B); $1.5 \mathrm{~mm}$ size at $9 \mathrm{~cm}$ distance (C); $2.0 \mathrm{~mm}$ size at $9 \mathrm{~cm}$ distance (D)

\section{Transgenic plant recovery and stability of the transformants}

Thirty four putative transformants were generated and 10 plants showed the presence of gus gene in PCR analysis (Figure 4). Stable GUS expression analysis in different plant parts of PCR positive plants revealed a strong GUS expression in seeds followed by bracts (Figure 5). The intensity of GUS gene expression was varying in different events. This may be due to the methylation of the cytosine residues of the introduced DNA (Southgate et al., 1995). Klein $\boldsymbol{e t}$ al. (1990) also observed the variation in GUS expression between the events derived from suspension culture by particle bombardment due to the variation in DNA methylation of introduced gene. 


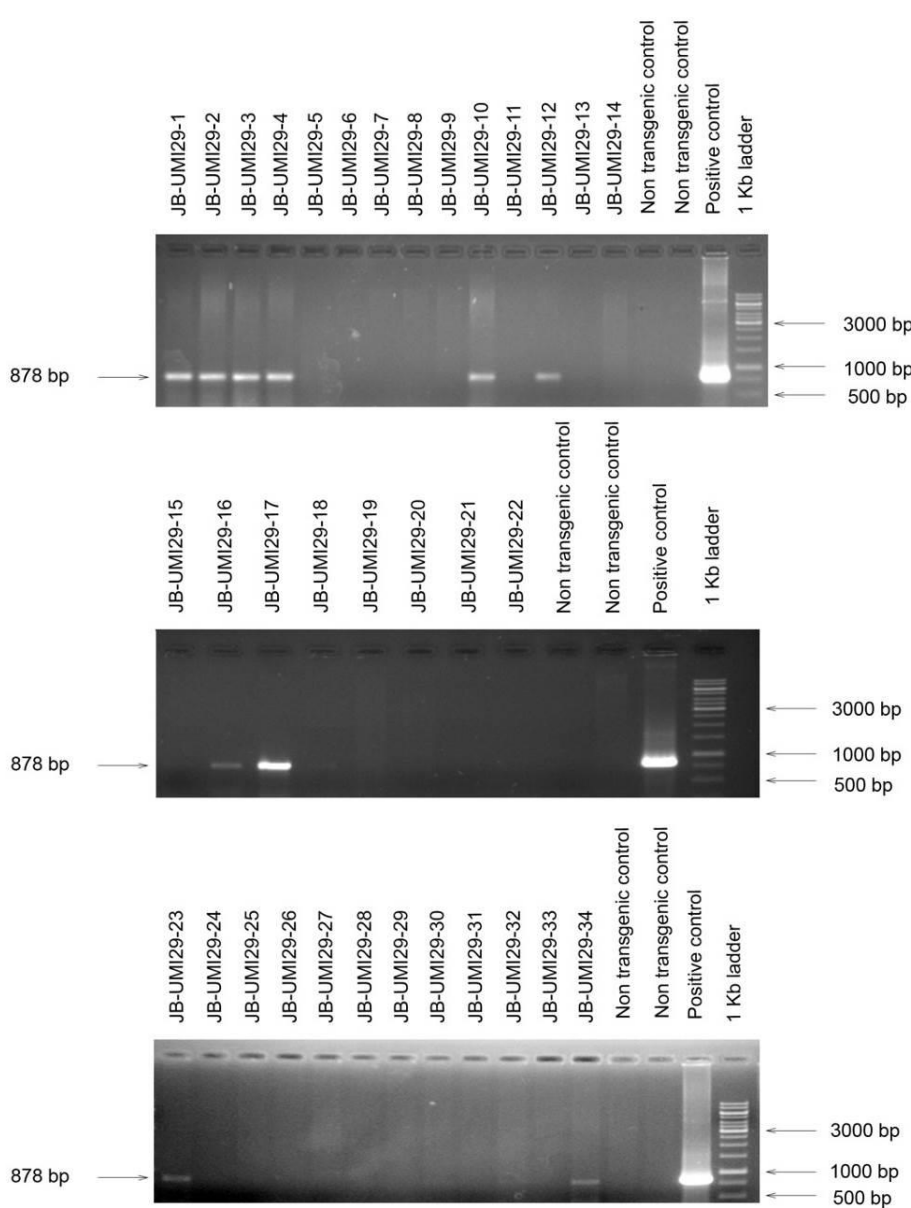

Figure 4 PCR amplification of gusA gene in putative transgenic maize lines transformed with pAHC25 vector
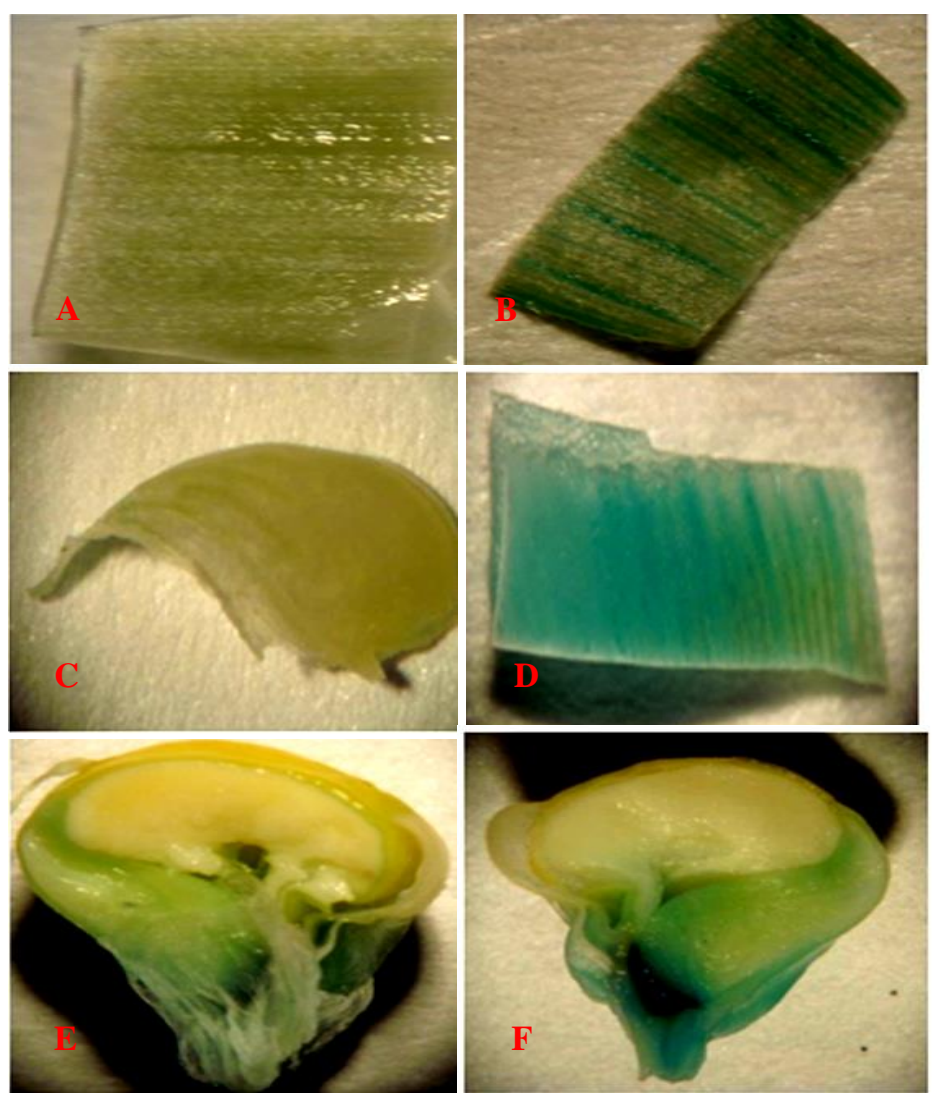

Figure 5 (A-F) GUS expression in different plant parts of control (nontransformed UMI29) and transgenic (transformed UMI29) plants: Leaf of control plant (A); Leaf of transgenic plant (B); Bract of control plant (C); Bract of transgenic plant (D); Seeds of control plant (E); Seeds of transgenic plant (F)
The most commonly used selectable marker gene in maize transformation is the bar or the pat gene (bialaphos or ammonium glufosinate resistance gene) (Gordon-Kamm et al., 1990; Valdez et al., 2004; Yan et al., 2010). Several earlier workers (Huang and Wei, 2005; Petrillo et al., 2008; Zhu et al., 2011 and Oneto et al., 2010) have demonstrated the expression of herbicide tolerance of transgenic maize harbouring bar gene by basta paining or spray. The positive transgenic plants which were generated by us in the present study were analysed for the expression of herbicide tolerance by Basta painting. The Basta swabbed area and the portion below the area turned yellowish and dried completely with the upper whorls of leaf showing chlorosis in control while in the transformed plants a slight yellowing was seen at the swabbed portion and other parts remained green (Figure 6)

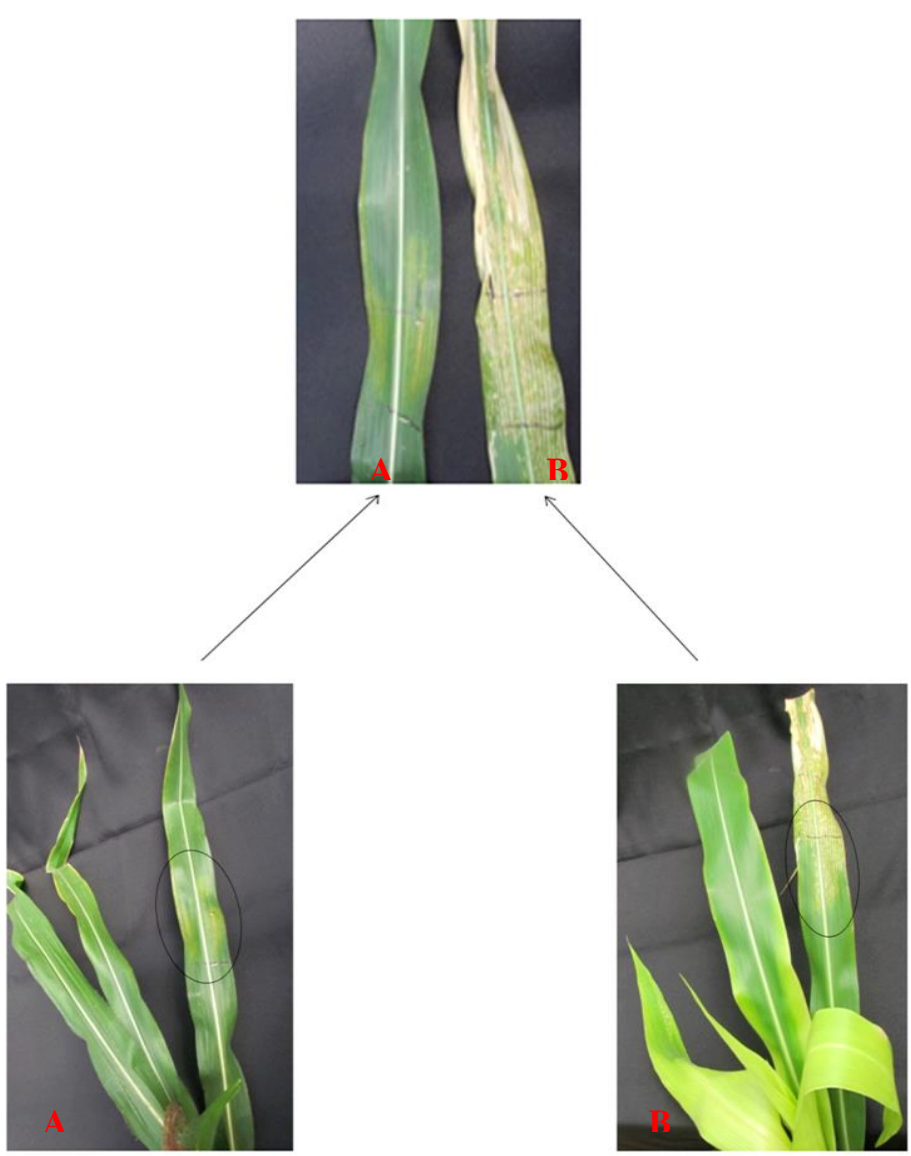

Figure $6(A, B)$ Basta painting assay: Transformed $T_{0}$ maize plant (A); Nontransformed (Control) UMI29 maize plant (B)

The interaction effect between the embryo size and microcarrier flying distance was significant and a maximum number of stable GUS expressing transgenic plants (4 plants) were generated from $1.5 \mathrm{~mm}$ long immature embryos bombarded at $6 \mathrm{~cm}$. Since the embryogenic calli developed from $1.5 \mathrm{~mm}$ long immature embryos were soft and fragile, the penetration of microprojectiles and subsequent integration of foreign DNA into the nuclear genome was efficient even at $9 \mathrm{~cm}$ distance, where the velocity of microprojectiles was low compared to $6 \mathrm{~cm}$ distance to penetrate harder tissue (3 plants; Tab 4). In contrast, deeper layers of scutellar tissue had to be targeted in $2.0 \mathrm{~mm}$ embryos. Kemper $\boldsymbol{e t}$ al. (1996) reported that the $3^{\text {rd }}$ or deeper layers of scutellar tissue can be targeted by using heavy bombardment procedures like $1800 \mathrm{psi}$ and $4.8 \mathrm{~cm}$ microcarrier flying distance. But the tissue damage must to be minimised by optimising the pre and post osmoticum treatments.

Table 4 Effect of microcarrier flying distance and embryo size on the production of stable GUS expressing plants and transformation. efficiency

\begin{tabular}{lccc}
\hline $\begin{array}{l}\text { Microcarrier } \\
\text { flying distance }\end{array}$ & Embryo size & $\begin{array}{c}\text { Stable gus } \\
\text { expressing } \\
\text { plants (Nos) }\end{array}$ & $\begin{array}{c}\text { Transformation } \\
\text { efficiency (\%) }\end{array}$ \\
\hline \multirow{2}{*}{$6 \mathrm{~cm}$} & $1.5 \mathrm{~mm}$ & 4 & 2.67 \\
& $2.0 \mathrm{~mm}$ & 2 & 1.33 \\
$9 \mathrm{~cm}$ & $1.5 \mathrm{~mm}$ & 3 & 2.00 \\
& $2.0 \mathrm{~mm}$ & 1 & 0.6 \\
\hline
\end{tabular}

Legend: Each treatment was replicated 5 times with 30 embryos per replication.

We recorded a maximum transformation efficiency of $2.67 \%$ at $6 \mathrm{~cm}$ microcarrier flying distance using $1.5 \mathrm{~mm}$ long-immature embryos compared to 9 
$\mathrm{cm}$ microcarrier flying distance $(1.33 \%$ for $1.5 \mathrm{~mm}$ and $0.6 \%$ for $2.0 \mathrm{~mm}$-long immature embryos; Tab 4). A similar report of decrease in transformation efficiency with increase in microcarrier flying distance was reported by Klein $\boldsymbol{e}$ al. (1988) and Aragao et al. (1993) but Taylor and Vasil (1991) reported visible damage to cells when the microcarrier flying distance was reduced, due to the cells being bombarded by large aggregates of gold.

The stability of the transgene in $\mathrm{T}_{1}$ generation was studied in JB-UMI29-2 and JB-UMI29-8 events. Thirteen out of nineteen and twenty two out of forty eight plants were found to be positive for GUS expression in JB-UMI29-2 and JBUMI29-8 events respectively (Tab 5). This demonstrated a stable inheritance of transgenes.

Table 5 Analysis of transgene segregation in $\mathrm{T}_{1}$ plants.

\begin{tabular}{|c|c|c|c|}
\hline \multirow{2}{*}{ Event No } & \multicolumn{2}{|c|}{ Number of seeds } & \multirow{2}{*}{$\begin{array}{c}\text { GUS expressing } \\
\text { plants }\end{array}$} \\
\hline & Sown & Germinated & \\
\hline JB-UMI29-2 & 30 & 19 & 13 \\
\hline JB-UMI29-8 & 50 & 48 & 22 \\
\hline
\end{tabular}

Though the transformation efficiency of temperate genotypes was as high as 17 $30 \%$ (Wang et al., 2009), tropical genotypes have recorded a maximum transformation frequency from 0.6 to $2.31 \%$ (Petrillo et al., 2008). Here, we report the highest transformation efficiency of $2.67 \%$ from an Indian tropical inbred, UMI29 for the first time using $1.5 \mathrm{~mm}$ long immature embryos at $6 \mathrm{~cm}$ of microcarrier flying distance.

\section{CONCLUSION}

Genetic transformation is one of the tools in crop improvement programs. To utilize these tools, transformation protocol for cultivars of regional importance needs to be standardized. In an attempt to develope a high frequency transformation protocol for Indian tropical inbred UMI29, we investigated different parameters which influence generation of transgenic plants. We achieved a transformation efficiency of $2.67 \%$ in an Indian tropical inbred, UMI29 using $1.5 \mathrm{~mm}$ long immature embryos at $6 \mathrm{~cm}$ of microcarrier flying distance. In future, the protocol developed by us can be followed in gentic transformation experiments to transfer various other useful genes.

\section{REFERENCES}

ARAGAO, F.J.L., GROSSI, M.F., DAVEY, M.R., BRASILEIRO, A.C.M. FARIA, J.C., RECH, E.L. 1993. Factors influencing transient gene expression in bean (Phaseolus vulgaris L.) using an electrical particle acceleration device. Plant Cell Reports, 12, 483-490. http://dx.doi.org/10.1007/BF00236092

ARMSTRONG, C.L., GREEN, C.E. 1985. Establishment and maintenance of friable, embryogenic maize callus and the involvement of L-proline. Planta, 164, 207-214. http://dx.doi.org/10.1007/BF00396083

BOHOROVA, N.E., LUNA, B., BRITON, R.M., HUERTA, L.D., HOISTINGTON D.A. 1995. Regeneration potential of tropical, subtropical, mid-altitude and highland maize inbreds. Maydica, 40, 275-281. http://dx.doi.org/10.5897/AJB08.857

BRETTSCHNEIDER, R., BECKER, D., LORZ, H. 1997. Efficient transformation of scutellar tissue of immature maize embryos. Theoretical and Applied Genetics, 94, 737-748. http://dx.doi.org/10.1007/s001220050473

CHRISTENSEN, A.H., QUAIL, P.H. 1996. Ubiquitin promoter-based vectors for high-level expression of selectable and/or screenable marker genes in monocotyledonous plants. Transgenic Research, 5, 213-218. http://dx.doi.org/10.1007/BF01969712

DANSON, J.W., LAGAT, M., BOGORI, M. 2006. Screening tropical maize lines for the production and regeneration of friable and embryogenic Type II callus. African Journal of Biotechnology, 5(23), 2367-2370.

DUNCAN, D., WILLIAMS, M.E., ZEHR, B.E., WIDHOLM, J.M. 1985. The production of callus capable of plant regeneration from immature embryos of numerous Zea mays genotypes. Planta, 165, 322-332. http://dx.doi.org/10.1007/BF00392228

El-ITRIBY, H.A., ASSEM, S.K., HUSSEIN, E.H.A., ABDEL-GALIL, F.M., MADKOUR , A.A. 2003 Regeneration and transformation of Egyptian maize inbred lines via immature embryo culture and a biolistic particle delivery system. In Vitro Cellular Developmentl Biology - Plant, 39, 524-531. http://dx.doi.org/10.1079/IVP2003439

FRAME, B., SHOU, H., CHIKWAMBA, R., ZHANG, Z., XIANG, C., FONGER, T., PEGGli, E., NETTlETON, B., PEI, D., WANG, K. 2002. Agrobacterium tumefaciens-mediated transformation of maize embryos using a standard binary vector system. Journal of Plant Physiology, 129, 13-22. http://dx.doi.org/10.1104/pp.000653
FRAME, B.R., ZHANG, H., COCCIOLONE, S.M., SIDORENKO, L.V., DIETRICH, C.R., PEGG, S.E., ZHEN, S., SCHNABLE, P.S., WANG, K. 2000. Production of transgenic maize from bombarded Type II callus: Effect of gold particle size and callus morphology on transformation efficiency. In Vitro Cellular Developmental Biology - Plant, 36, 21-29. http://dx.doi.org/10.1007/s11627-000-0007-5

GONZÁlEZ, G.A., PACHECO, M.G., ONETO, C.D., ETCHART, V.J., KANDUS, M.V., SALERNO, J.C. EYHERABIDE, G., PRESELLO, D., LEWI, D.M. 2012. Somatic embryogenesis and plant regeneration capacity in Argentinean maize (Zea mays) inbred lines. Electronic Journal of Biotechnology, 15(1), 7. http://dx.doi.org/10.2225/vol15issue1-fulltext-7

GORDON-KAMM, W.J., SPENCER, T.M., MANGANO, M.L., ADAMS, T.R., DAINES, $\quad$ R.J., $\quad$ START, W.J., O'BRIEN, J.V., CHAMBERS, S.A., ADAMS, W.R., WILLETTS, N.G., RICE T.B., MACKEY, C.J., KRUEGER, R.W., KAUSCH, A.P., LEMAUX, P.G. 1990. Transformation of maize cells and regeneration of fertile transgenic plants. Plant Cell, 2, 603- 618. http://dx.doi.org/10.1105/tpc. 2.7 .603

GREEN, C.E., PHILLIPS, R.L. 1975. Plant regeneration from tissue cultures of maize. Crop Science, 15, 417-421.

HODGES, T.K., KAMO, K.K., IMBRIE, C.W., BECWAR, M.R. 1986 Genotype specificity of somatic embryogenesis and regeneration in maize. Biotechnology, 4, 219-224. http://dx.doi.org/10.1038/nbt0386-219

HUANG, X., WEI, Z. 2004. High frequency plant regeneration through callus initiation from mature embryos of maize (Zea Mays L.). Plant Cell Reports, 22, 793-800. http://dx.doi.org/10.1007/s00299-003-0748-9

ISHIDA, Y., SAITO, H., OHTA, S., HIEI, Y., KOMARI, T., KUMASHIRO, T. 1996 High efficiency transformation of maize (Zea mays L.) mediated by Agrobacterium

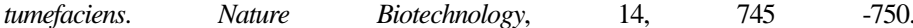
http://dx.doi.org/10.1038/nprot.2007.241

JAKUBEKOVÁ, M., PREŤOVÁ, A., OBERT, B. 2011. Somatic embryogenesis and plant regeneration from immature embryo induced callus of maize (Zea mays). Journal of Microbiology Biotechnology and Food science, 1(4), 478-487. JEFFERSON, R.A. 1987. Assaying chimeric genes in plants: the GUS gene fusion system. Plant Molecular Biology Reporter, 5, 387-405. http://dx.doi.org/10.1007/BF02667740

KAUSCH, A.P., ADAMS, T.R., MANGANO, M., ZACHWIEJA, S.J., $\begin{array}{lll}\text { GORDON-KAMM, } & \text { W., } & \text { DAINES, }\end{array}$ CHAMBERS, S.A., ADAMS, W.R., ANDERSON, A., WILLIANS, G., HAINES, G. 1995. Effects of microprojectile bombardment on embryogenic suspension cell cultures of maize (Zea mays L.) used for genetic transformation. Planta, 196, 501-509. http://dx.doi.org/10.1007/BF00203650

KEMPER, E.L., SILVA, M.J., ARRUDA, P. 1996. Effect of microprojectile bombardment parameters and osmotic treatment on particle penetration and tissue damage in transiently transformed cultured immature maize (Zea mays L.) embryos. Plant Science, 121, 85-93. http://dx.doi.org/10.1016/S01689452(96)04500-1

KLEIN, T.M., GRADZIEI, T., FROMM, M.E., SANFORD, J.C. 1988. Factors influencing gene delivery into Zea mays cells by high-velocity microprojectiles. Nature Biotechnology, 6, 559-563. http://dx.doi.org/10.1038/nbt0588-559

KLEIN, T.M., KOMSTEIN, L., FROMM, M.E. 1990. Genetic transformation of maize cells by particle bombardment and the influence of methylation on foreigngene expression. New York : Gene Manipulation in Plant Improvement II, 265 288 p. ISBN 978-1-4684-7047-5.

KRAKOWSKY, M.D., LE, M., GARAY, L., WOODMAN-CLIKEMAN, W. LONG, M.J., SHAROPOVA, N., FRAME, B., WANG, K. 2006. Quantitative trait loci for callus initiation in maize (Zea mays L.). Theoretical Applied Genetics, 113(5), 821-830. http://dx.doi.org/10.1007/s00122-006-0334-y

MANIVANNAN, A., KAUL, J., SINGODE, A., DASS, S. 2010. Callus induction and regeneration of elite Indian maize inbreds. African Journal of Biotechnology, 9(44), 7446-7452.

MILLER, M., TAGLIANI, L., WANG, N., BERKA, B., BIDNEY, D., ZHAO, Z 2002. High efficiency transgene segregation in co-transformation maize plants using an Agrobacterium tumefaciens 2 T-DNA binary system. Transgenic Research, 11, 381-396. http://dx.doi.org/10.1023/A:1016390621482

NEGROTTO, D., JOLLEY, M., BEER, S., WENCH, A.R., HANSEN, G. 2000 The use of phosphomannose-isomerase as a selectable marker to recover transgenic maize plants (Zea mays L.) via Agrobacterium transformation. Plant Cell Reports, 19, 798-803. http://dx.doi.org/10.1007/s002999900187

ONETO, D.C., BOSSIO, E., GONZALEZ, G., FACCIO, P., LEWI, D. 2010 High and low pressure gene gun devices give similar transformation efficiencies in maize calluses. African Journal of Plant Science, 4(7), 217-225.

PETRILlO, C.P., CARNEIRO, N.P., PURCINO, A.Á.C., CARVALHO, C.H.S., ALVES, J.D., CARNEIRO, A.A. 2008. Optimization of particle bombardment parameters for the genetic transformation of Brazilian maize inbred lines. Pesq Agropec Bras, 43(3), 371-378. http://dx.doi.org/10.1590/S0100204X2008000300012 
RAFIQ, M., FATIMA, T., HUSNAIN, T., BASHIR, K., RIAZUDDIN, S. 2005. Effect of different media on callus formation and regeneration of different genotypes of maize (Zea mays L.). Plant Tissue Culture, 15(1), 57-65.

SANFORD, J.V., SMITH, F.D., RUSSELL, J.A. 1993. Optimising the biolistic process for different biological applications. Methods Enzymology, 217, 483-509. http://dx.doi.org/10.1016/0076-6879(93)17086-K

SOUTHGATE, E.M., DAVEY, M.R., POWER, J.B., Marchant, R. 1995. Factors affecting the genetic engineering of plants by microprojectile bombardment Biotechnology Advances, 13(4), 631-651. http://dx.doi.org/10.1016/07349750(95)02008-X

TADESSE, Y., SÁGI, L., SWENNEN, R., JACOBS, M. 2003. Optimisation of transformation conditions and production of transgenic sorghum (Sorghum bicolor) via microparticle bombardment. Plant Cell Tissue and Organ Culture, 75, 1-18. http://dx.doi.org/10.1023/A:1024664817800

TAYLOR, M.G., VASIL, I.K. 1991. Histology and physical factors affecting, transient GUS expression in pearl millet (Pennisetum glaucum (L.) R. Br.) embryos following micoprojectile bombardment. Plant Cell Reports, 10, 120125. http://dx.doi.org/10.1007/BF00232041

TOMES, D.T., SMITH, O.S. 1985. The effect of parental genotype on initiation of embryogenic callus from elite maize (Zea mays L.) germplasm. Theoretical Applied Genetics, 70, 505-509. http://dx.doi.org/10.1007/BF00305983

VALDEZ, M., MADRIZ, K., RAMÍREZ, P. 2004. A method for genetic transformation of maize for resistance to viral diseases. Revista de Biologia Tropical, 52(3), 787-793.

VASIL, V., LU, C.Y., VASIL, I.K. 1985. Histology of somatic embryogenesis in cultured immature embryos of maize (Zea mays L.). Protoplasma, 127, 1-8. http://dx.doi.org/10.1007/BF01273696

WANG, K., FRAME, B., ISHIDA, Y., KOMARI, T. 2009. Maize transformation. New York : Handbook of maize: genetics and genomics, 609-640 p. ISBN 978-0-387-77863-1.

www.igc.int retrived on 10. 4. 2014.

YAN, J., BERMUDEZ-KANDIANIS, C., HARJES, C., BAI, L., KIM, E., YANG, X., SKINNER, D., FU, S., MITCHELL, S., LI, Q., SALAS, M., FERNANDEZ, M., ZAHARIEVA, R., BABU, Y., FU, N.A., PALACIOS, J., LI, D., DELLAPENNA, T., BRUTNELL, E., BUCKLER, M., WARBURTONTORBERT, R. 2010. Rare genetic variation at Zea mays crtRB1 increases $\beta$ carotene in maize grain. Nature Genetics, 42, 322-327. http://dx.doi.org/10.1038/ng.551

ZHU, Y., ZHAO, F., ZHAO, D. 2011. Regeneration and transformation of a maize elite inbred line via immature embryo culture and enhanced tolerance to a fungal pathogen Exserohilum turcicum with a balsam pear class I chitinase gene. African Journal of Agricultural Research, 6(7), 923-930. http://dx.doi.org/10.5897/AJAR10.1174 